\title{
ANALYSIS OF SERVICE QUALITY SATISFACTION OF E-KTP SERVICE AT PUBLIC ADMINISTRATION AND CIVIL REGISTRATION OFFICE OF BOGOR DISTRICT
}

\author{
ShafiraRizq $^{1 *)}$, Moh. DjemdjemDjamaludin ${ }^{2}$, Yani Nurhadryani $^{3}$ \\ ${ }^{1,2}$ Department of Family and Consumer Sciences, Faculty of Human Ecology, Bogor \\ Agricultural University, Bogor, 16680 \\ ${ }^{3}$ Department of Computer Science, Faculty of Mathematics and Natural Sciences \\ Bogor Agricultural University, Bogor, 16680 \\ ${ }^{*}$ Corresponding author: shafirarizq@gmail.com
}

\begin{abstract}
The purpose of this study was to analyze the satisfaction of service quality in the E-KTP service of the Bogor District Population and Civil Registration Service. The design of this study was a cross-sectional study at Disdukcapil Bogor District. The method used in this study is Servqual, importance performance analysis (IPA), and customer satisfaction index (CSI) with 100 respondents selected by convenience technique. The result of customer satisfaction index analysis shows that the community has been "quite satisfied" with a value of $61 \%$, and is more inclined towards dissatisfaction. This is in accordance with the results of satisfaction obtained fromServqual analysis (service quality), Disdukcapil's performance has not been able to meet the expectations of the community in almost all indicators, except the indicator "costs to be incurred". The indicator has a positive value, but is still small and close to zero, which is only 0.01 . The results of importance performance analysis (IPA) indicate that there is a need for the indicators to be improved in terms of the ease of handling requirements, speed of service processes and facilities and physical condition of service office buildings.
\end{abstract}

Keywords: Disdukcapil, E-KTP, satisfaction, service quality, Servqual

\begin{abstract}
Abstrak
Tujuan dari penelitian ini adalah menganalisis kepuasan kualitas pelayanan pada pelayanan E-KTP Dinas Kependudukan dan Catatan Sipil Kabupaten Bogor. Desain penelitian ini adalah cross-sectional study di Disdukcapil Kabupaten Bogor. Metode yang digunakan dalam penelitian ini adlaah Servqual, importance performance analysis (IPA), dan customer satisfaction index (CSI) dengan 100 responden yang dipilih menggunakan convenience technique. Hasil analisis customer satisfaction index menunjukan bahwa masyarakat sudah "cukup puas" dengan nilai $61 \%$, dan lebih condong ke arah tidak puas. Hal tersebut sesuai dengan hasil kepuasan menggunakan analisis Servqual (service quality), kinerja Disdukcapil belum dapat memenuhi harapan masyarakat di hampir semua indikator, kecuali indikator "biaya yang harus dikeluarkan". Indikator tersebut memiliki nilai positif, namun masih dibilang kecil dan mendekati nilai nol, yaitu hanya 0.01. Hasil importance performance analysis (IPA) menunjukan perlu adanya perbaikan pada indikator kemudahan pengurusan
\end{abstract}


persyaratan, kecepatan proses pelayanan dan fasilitas dan keadaan fisik gedung kantor pelayanan.

Kata kunci: Disdukcapil, E-KTP ,kepuasan, kualitas pelayanan, Servqual

\section{Introduction}

Currently there are several problems occurred related to public services, such as E-KTP services (electronic identity cards). One of the problem is the long waiting time for services. The waiting time for registration and recording in this service varies, some are completed in minutes, hours, or even days because people still have to return the next day to complete the service. In fact, to obtaina printed E-KTP itself, there are some people who have to wait for months, even years. This certainly makes people become dissatisfied with the existing public services, hence the public demands for an improvement in public services.

Recently, public demands forbetter quality public services is increasing, which agrees with the number of population in Indonesia, which is approximately 258 million people (BPS, 2017), thus definitely more people will need better public services, especially for E-KTP registration. Refer to Law No. 24 of 2013 Article 63 concerning the Population Administration, Indonesian citizens and foreigners who have permanent residence permit,aged 17 (seventeen) years old or who have been married must have an eligible KTP. The implementation of the E-KTP service is carried out by the Department of Population and Civil Registration (Disdukcapil), with the sub-district as the service branch.

The Civil Service Office of Bogor District has currently started to use an integrated online system called SIAK (Population Administration Information System) to organize population administration systems such as E-KTP cards, birth certificates, family registration etc. In Disdukcapil Bogor District, this system can only be accessed by employees, while citizens still haveto come and register at the Disdukcapil and queueto get the services they need. Although this system allows employees to organize administration data online, but for people who want to get E-KTP services, still have to come to the office to queue and cannot access the services online.

Many Indonesians use the internet for online activities, according to the 2017 Indonesian Internet Association Association's (APJII) survey, internet users in Indonesia have reached approximately 143 million people. This shows that Indonesian people are already familiar with internet for daily use, and Disdukcapil can benefit from this to provide an online system for the community. The system created must also be adjusted to the user, hence a careful strategy for better improvement and development of services planning is needed to fulfil citizen's needs for service.

An evaluation of public services is needed in advance to plan an appropriate strategy to answer to the needs of the citizen as the service users at Disdukcapil Bogor District, especially in the E-KTP section. According to Regulation of the Minister of Administrative Reform and Bureaucratic Reform 2014, evaluation is needed for quality improvement of public services on an ongoing basis. Thus in development planning, a 
plan can be developed to create a services by adjusting to the needs of the citizen themselves.

Akinboade et al (2012) stated that comments from the public are needed by the service provider hence service improvement can be carried out effectively. Aform of comment that can be measured is satisfaction. According to Sumarwan (2015), satisfaction is a comparison between consumer expectations and actual service reality. Therefore, satisfaction can be used to evaluate and improve services effectively. One way to measure service satisfaction through an observation of the quality of their services, using the Servqual (service quality) method developed by Parasuraman (1985). This method analyzes the results of the comparison between expectations and performance of consumers on service quality. Service quality is divided into fivedimensions, namely reliability, responsiveness, assurance, empathy and tangibles.

Based on explanation above, it is necessary to performa research on satisfaction of E-KTP services in order to improve the quality of E-KTP services in Disdukcapil Bogor District. This study aims to analyze the satisfaction of E-KTP services in Disdukcapil Bogor District using the Servqual and Customer Satisfaction Index (CSI) methods, and to analyse the quality of E-KTP service in Bogor District Disdukcapil using the Importance Performance Analysis (IPA) method.

\section{Method}

This study used a cross sectional study design, and employed a survey method. The study was conducted at Population and Civil Registration Service Bogor District Office. The selection of research location was carried out purposively, where based on data, Bogor District had a total population of 5,587,390 people, which made Bogor District as the most populous district in West Java Province (BPS 2017). In order to get a picture of existing condition, this study used a convenience technique to select the sample. The sample were selected in the target location and they were asked to become a respondent. This study analyzed 100 respondents who used E-KTP service at Disdukcapil Bogor District on 13-25 April 2018.

Primary data was obtained from interviews toward respondents using questionnaire tools. The analysis that used in this study isServqual method, Customer Satisfaction Index (CSI), and the Importance Performance Analysis (IPA). The questionnaire in this study adopted a Servqual questionnaire from previous research conducted by Riyadi et al (2015), as well as a community satisfaction survey questionnaire on the implementation of public services, taken from the Minister of Administrative Reform and Republic of Indonesia's regulation number 16 of 2014. Service quality instruments consisted of 22 questions which was divided into five dimensions, that is: 5 questions for the reliability dimension, 3 questions for the responsive dimension, 5 questions for the guarantee dimension, 5 questions for the empathy dimension, and 4 questions for the dimension of physical evidence. Satisfaction is then measured based on the level of expectations and level of performance. The value of cronbach's alpha for service quality was 0.777 and the value of cronbach's alpha for service quality performance was 0.745 .

\section{Servqual}

Satisfaction of service quality is measured based on the level of expectations and performance which are divided into five dimensions, that is: reliability, responsiveness, 
assurance, empathy, and tangibles. In these five dimensions there are statementsare in pairs, within the same content, one is statement for their expectation, and the other is a statement for their perception of service quality, the scores for each pair can be calculated based on the following formula (Zeithaml et al 1990 in Tjiptono and Chandra 2016)

\section{SERVQUALScore $=$ Performance Score-Expectation}

Details of the gap score calculation for service quality can also be done in various levels as follows :

1. Item-by-item analysis : for exampleP1-E1, P2-E2

2. Dimension-bydimension analysis : $(\mathrm{P} 1+\mathrm{P} 2+\mathrm{P} 3+\mathrm{P} 4 / 4)-(\mathrm{E} 1+\mathrm{E} 2+\mathrm{E} 3+\mathrm{E} 4 / 4)$, withP1toP4andE1 toE4represent fourperformance and expectation statements concerning a certain dimension.

3. Calculation of single size of service quality or Servqual gap: $(\mathrm{P} 1+\mathrm{P} 2+\mathrm{P} 3+\mathrm{P} 4$ $+\ldots+\mathrm{P} 22 / 22)-(\mathrm{E} 1+\mathrm{E} 2+\mathrm{E} 3+\mathrm{E} 4+\ldots+\mathrm{E} 22 / 22) \mathrm{P} 1$ toP22andE1 toE22arethe whole expectation and performance statements.

The level of satisfaction is measured using the Servqual model and analyzed with a gap analysis. Servqual method observes the gap between expectations of services that will be expected (perceived service) with actual services perceived by customers (perceived service), in this model if the performance of an attribute (attribute performance) is greater than the expectations of the attributes concerned, then the perception of service quality will be positive and vice versa (Tjiptono and Chandra 2016).

\section{Customer Satisfaction Index}

CSI analysis was used to evaluate consumer experience in purchasing and usage, both actual and expected (Anderson et al, 1994 in Anderson and Fornell, 2000). The CSI is an index to determine the level of customer satisfaction thoroughly, this method also considers the importance of the attributes to be measured (Husna and Syukri 2014). According to Amran and Ekadeputra (2014) the stages in measuring CSI can be divided into four, that is:

1. To calculate the weighted factor by changing the average level of importance to a percent, hence the total weighting factor is $100 \%$.

2. To calculate the weighting score, which is the multiplication value between the average value of the performance level and the weighting factor.

3. To calculate total weighted, add the weighted score of all attributes

4. To calculate satisfaction index, namely the total weighted divided by the maximum scale used (in this study the maximum scale used is 5) then multiplied by $100 \%$. 
The obtained percentage resultsindicatethe category of respondents satisfaction positions. The CSI categories can be seen in Table 1 .

Table1Guide to customer satisfaction indexof PT Sucofindo satisfaction survey

\begin{tabular}{lll}
\hline No & Index Score $(100 \%)$ & Category \\
\hline 1. & $81 \%-100 \%$ & Very satisfied \\
2. & $66 \%-80.99 \%$ & Satisfied \\
3. & $51 \%-65.99 \%$ & Quite satisfied \\
4. & $35 \%-50.99 \%$ & LessSatisfied \\
5. & $0 \%-34.99 \%$ & Not satisfied \\
\hline
\end{tabular}

Source :Windyaniet al 2014

\section{Importance Performance Analysis}

Furthermore, Importance Performance Analysis (IPA) method was used to analyze the service quality. IPA provides a focus to develop a service quality improvement strategy. The results of IPA are displayed in a quadrant, which allows managers to easily find and interpret, also to make decisions, because each quadrant is linked to certain strategies to allocate resources (Charaf and Rahmouni, 2014)

IPA method consists of coordinate axis pairs, where axis performance is represented by $\mathrm{x}$-axis and importance represented by $\mathrm{y}$-axis, various performance elements and importance involved in service are compared and ultimately divided into 4 quadrants (Martilla and James 1977 in Chen 2018):

1. Quadrant 1 (Concentrate here) : In this quadrant consumers feel that some services are important, but there are indications of low satisfaction with the performance given. This zone forms a priority for service providers and resources must be invested in this quadrant.

2. Quadrant2 (Keep up the good work) : This quadrant consist of items that have high interest and performance. Attributes in this quadrant provide an opportunity to achieve or maintain the advantages of the service.

3. Quadrant3 (Low priority) : This quadrant consists of items that have an indication of low interest and performance, consumers do not care about the attributes of this quadrant, hence there is no need to resource allocation or additional effort for items in this quadrant.

4. Quadrant4 (Possible overkill) : High performance attributes but low interests. Services in this quadrant work well, but consumers have little interest in the service. This quadrant indicates that the resources given to items in this quadrant can be reduced or reallocated to more important attributes of consumers.

\section{Findings and Discussion}

\section{Respondent Characteristics}

Primary data was collected from 105 respondents who used E-KTP services in the E-KTP service room of Disdukcapil Bogor District.After data cleaning, only 100 respondents thatwere suitable for the study., that is, 53 female, and 47 male. In term of the last education, six of ten respondents had completed high school / equivalent, and only one respondent did not complete elementary school. Based on BPS age division (2017), nearly four in ten respondents were in the group of 15-19 year old and nearly a quarter of respondents were in the 20-24 year oldranges. The average 
respondent'sexpenditure was Rp. 2,174,100, with about a half ofrespondents falling into the category of $\leq$ Rp. $1,000,000$.

\section{Satisfaction Analysis Using Gap Analysis with Servqual Method}

The result of gap analysis with the Servqual method, showed that most of the expectations of E-KTP service users on the service performance have not been fulfilled. This analysis is further elaborated in Table 2. Almost all results of calculations per performance item and expectations still obtaina negative value, except on item 4 that is,"Costs that must be incurred" with a positive value, however itis still very small and near to zero with a value of 0.01 .

Based on Servqual value per dimension, there is no dimension that has a positive value.This means that there is no dimension of service quality that meets the expectations of respondents. This is consistent with the research conducted by Windyani et al (2014) regarding service birth certificate in Depok, Hirmukhe's (2012) study of the quality of administrative services in India and the study of Haq and Suharso(2014) regarding the quality of E-KTP services in Suboh Sub-district, Situbondo District, in which these explained that all Servqual scores in each dimension were negative. People still feel that there is still a lack of information regardingservice schedules, insufficient speed of service, lack of discipline in officers, unavailability of procedures for complaints and suggestions, and the lack of understanding on how to provide complaints and suggestions to Disdukcapil, as well as the lack of facilities and physical condition of the building.

The biggest negative gap analysis is in the empathy section. This section shows that Disdukcapil have to be very attentive on this dimension, because there is a large gap between citizens' expectations and the performance given by Disdukcapil. The empathy dimension in this study includes easy service procedures, available information regardingcosts, availability of information on service standards, availability of procedures for complaints and suggestions, and ease of understanding of the complaints mechanism. The items with the highest negative value are item 17 and 18, that is,the availability of procedures for complaints and suggestions, and the ease of understanding the complaints mechanism.

The citizens in Disdukcapil Bogor District did not know the availability of the complaints and suggestions process even though they had suggestions and complaints to be given, the citizens also did not know the mechanism of the process to provide complaints and suggestions to Disdukcapil Bogor District. Complaints of advice is a form of democratic practice in public services, which is to provide the opportunity for the community to submit complaints where the services they receive are not in line with expectations or not in accordance with what was promised by the service provider (BAPPENAS 2010).

Table2The results of the gap analysis variable service quality with Servqual method

\begin{tabular}{|c|c|c|c|c|}
\hline \multirow{2}{*}{$\begin{array}{l}\text { No. } \\
\text { Item }\end{array}$} & \multirow{2}{*}{ Indicator } & \multicolumn{2}{|c|}{ Average per item } & \multirow{2}{*}{$\begin{array}{l}\text { Performance- } \\
\text { Expectation }\end{array}$} \\
\hline & & Performance & Expectation & \\
\hline \multicolumn{5}{|c|}{ Reliability } \\
\hline 1. & $\begin{array}{l}\text { Clear Information of services } \\
\text { Requirements }\end{array}$ & 3.2 & 4.49 & -1.29 \\
\hline 2. & Ease of handling requirements & 2.98 & 4.51 & -1.53 \\
\hline 3. & Service schedule information & 2.58 & 4.35 & -1.77 \\
\hline
\end{tabular}




\begin{tabular}{|c|c|c|c|c|}
\hline \multirow{2}{*}{$\begin{array}{l}\text { No. } \\
\text { Item }\end{array}$} & \multirow{2}{*}{ Indicator } & \multicolumn{2}{|c|}{ Average per item } & \multirow{2}{*}{$\begin{array}{l}\text { Performance- } \\
\text { Expectation }\end{array}$} \\
\hline & & Performance & Expectation & \\
\hline 4. & Costs of services & 4.23 & 4.22 & 0.01 \\
\hline 5. & Compliance with service standards & 2.79 & 4.18 & -1.39 \\
\hline \multicolumn{2}{|c|}{ Average } & 3.156 & 4.35 & \\
\hline \multicolumn{2}{|c|}{ Servqual Score (performance-expectation) } & \multicolumn{2}{|c|}{-1.194} & \\
\hline \multicolumn{5}{|c|}{ Responsive } \\
\hline 6. & Service process speed & 2.4 & 4.51 & -2.11 \\
\hline 7. & $\begin{array}{l}\text { The ability of officers to provide clear } \\
\text { information }\end{array}$ & 3.48 & 4.43 & -0.95 \\
\hline 8. & $\begin{array}{l}\text { The ability of officers to be responsive } \\
\text { in providing services }\end{array}$ & 3.32 & 4.42 & -1.1 \\
\hline \multicolumn{2}{|c|}{ Average } & 3.067 & 4.453 & \\
\hline Servqu & al Score (performance-expectation) & \multicolumn{2}{|c|}{-1.387} & \\
\hline \multicolumn{5}{|c|}{ Asurance } \\
\hline 9. & Officer politeness & 3.75 & 4.53 & -0.78 \\
\hline 10. & Officer discipline & 3.41 & 4.53 & -1.12 \\
\hline 11. & Officer hospitality & 3.6 & 4.55 & -0.95 \\
\hline 12. & Officer appearance & 3.78 & 4.56 & -0.78 \\
\hline 13. & $\begin{array}{l}\text { Availability of information about types } \\
\text { of services }\end{array}$ & 2.76 & 4.08 & -1.32 \\
\hline \multicolumn{2}{|c|}{ Average } & 3.46 & 4.45 & \\
\hline Servqu & al Score (performance-expectation) & \multicolumn{2}{|c|}{-0.99} & \\
\hline \multicolumn{5}{|c|}{ Empathy } \\
\hline 14. & Easy service procedure & 3.14 & 4.46 & -1.32 \\
\hline 15. & Service fee information is available & 3.46 & 4.27 & -0.81 \\
\hline 16. & $\begin{array}{l}\text { Availability of service standard } \\
\text { information }\end{array}$ & 2.24 & 4.22 & -1.98 \\
\hline 17. & $\begin{array}{l}\text { Availability of procedures for } \\
\text { complaints and suggestions }\end{array}$ & 2.05 & 4.29 & -2.24 \\
\hline 18. & $\begin{array}{l}\text { Ease of understanding the mechanism } \\
\text { of complaints and suggestions }\end{array}$ & 1.94 & 4.3 & -2.36 \\
\hline \multicolumn{2}{|c|}{ Average } & 2.566 & 4.308 & \\
\hline \multirow{2}{*}{\multicolumn{2}{|c|}{$\begin{array}{l}\text { Servqual Score (performance-expectation) } \\
\text { Tanoible }\end{array}$}} & \multicolumn{2}{|c|}{-1.742} & \\
\hline & & & & \\
\hline 19. & $\begin{array}{l}\text { Available information on service } \\
\text { procedures (websites, brochures, etc.) }\end{array}$ & 3.14 & 4.43 & -1.29 \\
\hline 20. & Affordability of service locations & 3.09 & 4.49 & -1.4 \\
\hline 21. & $\begin{array}{l}\text { Facilities and physical condition of } \\
\text { office buildings }\end{array}$ & 2.86 & 4.48 & -1.62 \\
\hline 22. & Service room comfort & 2.8 & 4.2 & -1.4 \\
\hline \multicolumn{2}{|c|}{ Average } & 2.972 & 4.4 & \\
\hline \multirow{2}{*}{\multicolumn{2}{|c|}{$\begin{array}{l}\text { Servqual Score (performance-expectation) } \\
\text { Servqual Score Average }\end{array}$}} & \multicolumn{2}{|c|}{-1.427} & \\
\hline & & \multicolumn{2}{|c|}{-1.348} & \\
\hline
\end{tabular}

At the end of the interview, respondents were re-asked about their opinions on overall service quality satisfaction. Sixpercent of respondent chose very satisfied, a quarter of respondent reported satisfied, and more than half of the respondents chose quitesatisfied (56\%) as their answer to overall satisfaction for the quality of service provided by Disdukcapil. Meanwhile, 12 percent of respondents were dissatisfied, and 1 percent chose very dissatisfied. These answers showthat the community wants to improve the quality of service from Disdukcapil Bogor District.

Satisfaction of E-KTP Service Quality Using Customer Satisfaction Index Analysis 
Table 3 shows the results of the assessment on customer satisfaction with the Customer Satisfaction Index analysis.. The result of the calculation is $61 \%$ which means that the public perception of the satisfaction of the quality of E-KTP service falls in the category of "Quite Satisfied" in accordance with the distribution of satisfaction category in Table 1, with values in the range of $51 \%-65.99 \%$.

Table 3 Analysis of consumer satisfaction using the customer satisfaction index method

\begin{tabular}{|c|c|c|c|}
\hline No & Indicator & $\begin{array}{l}\text { Weighted } \\
\text { Factor }\end{array}$ & $\begin{array}{c}\text { Weighted } \\
\text { Score }\end{array}$ \\
\hline & Reliability & & \\
\hline 1. & Clear Information of services Requirements & 0.05 & 0.149 \\
\hline 2. & Ease of handling requirements & 0.05 & 0.139 \\
\hline 3. & Service schedule information & 0.05 & 0.116 \\
\hline 4. & Costs of services & 0.04 & 0.185 \\
\hline \multirow[t]{2}{*}{5.} & Compliance with service standards & 0.04 & 0.121 \\
\hline & Responsive & & \\
\hline 6. & Service process speed & 0.05 & 0.112 \\
\hline 7. & The ability of officers to provide clear information & 0.05 & 0.159 \\
\hline \multirow[t]{2}{*}{8.} & The ability of officers to be responsive in providing services & 0.05 & 0.152 \\
\hline & Assurance & & \\
\hline 9. & Officer politeness & 0.05 & 0.176 \\
\hline 10. & Officer discipline & 0.05 & 0.160 \\
\hline 11. & Officer hospitality & 0.05 & 0.169 \\
\hline 12. & Officer appearance & 0.05 & 0.178 \\
\hline \multirow[t]{2}{*}{13.} & Availability of information about types of services & 0.04 & 0.117 \\
\hline & Empathy & & \\
\hline 14. & Easy service procedure & 0.05 & 0.145 \\
\hline 15. & Service fee information is available & 0.04 & 0.153 \\
\hline 16. & Availability of service standard information & 0.04 & 0.097 \\
\hline 17. & Availability of procedures for complaints and suggestions & 0.04 & 0.091 \\
\hline \multirow[t]{2}{*}{18.} & Ease of understanding the mechanism of complaints and suggestions & 0.04 & 0.086 \\
\hline & 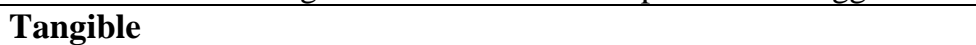 & & \\
\hline 19. & $\begin{array}{l}\text { Available information on service procedures (websites, brochures, } \\
\text { etc.) }\end{array}$ & 0.05 & 0.144 \\
\hline 20. & Affordability of service locations & 0.05 & 0.144 \\
\hline & Facilities and physical condition of office buildings & 0.05 & 0.132 \\
\hline 22. & Service room comfort & 0.04 & 0.121 \\
\hline \multicolumn{2}{|c|}{ Weighted Total } & & 3.052 \\
\hline \multicolumn{2}{|c|}{ Customer Satisfaction Index Total } & & $61 \%$ \\
\hline
\end{tabular}

Although this number fit into "quite satisfied", the result of gap analysis showed that only one expectation of item is met with a small score, near zero, means that almost all of the expectation toward Disdukcapil is not met yet. This means that the "quite satisfied" category is more inclined towar dissatisfaction.

\section{Analysis of Service Quality with Importance Performance Analysis}

Figure 1 shows a Cartesian diagram of the Importance Performance Analysis. This diagram divides items into 4 quadrants according to the average expectation and performance of each item, $\mathrm{X}$ axis line is determined from the average performance (3.045) while the $\mathrm{Y}$ axis line is obtained from average expectations (4.38).

Disdukcapil can improve the quality of their service satisfaction by observing quadrant 1 (high priority) items, where people have high expectations toward the items, but the performance given is still lacking. Quadrant 1 has three items, that is ease of 
handling requirements, speed of service process, facilities and physical condition of office buildings, with the speed of the service process as the item that holds the highest expectation. In its implementation, Disdukcapil has not been able to provide fast service according to public perception, there is a chance that this problem happendue to the lack of human resources in E-KTP services, the large number of people who come to E-KTP services, and the lack of facilities or systems that can make the process more efficient and effective and the queue is less clear.

The results show that almost half of the total items (10) are in quadrant 2 (keep up the good work) which means that items in this quadrant already have the good balance betweenexpectations and performance. Items that have the highest score in term ofexpectation and performance are employees.The community agrees that they want the service officers as government officials to look clean and tidy, and Disdukcapil can perform this, hence Disdukcapil needs to maintain their performance of indicators in this quadrant.

The items in Quadrant 3 (low priority) have a low priority and performance compared to other items. One of the items with low priority is the availability of information on the type of service, hence the resources in this item can be moved to other items that need more resources to increase the performance in quadron 1.

The next quadrant is Quadrant 4 (possible overkill).There are two items in this quadrant, these items have a high performance value, but low expectations, which means the items are not considered too important by the public but its performance is excessive. One of the items with the lowest expectation value in this quadrant is 'the cost that must be incurred'. The public is not too concerned with the cost, and prefers good service, and is willing to pay for the service.Resources in this quadrant can be transferred to other resources to increase satisfaction.

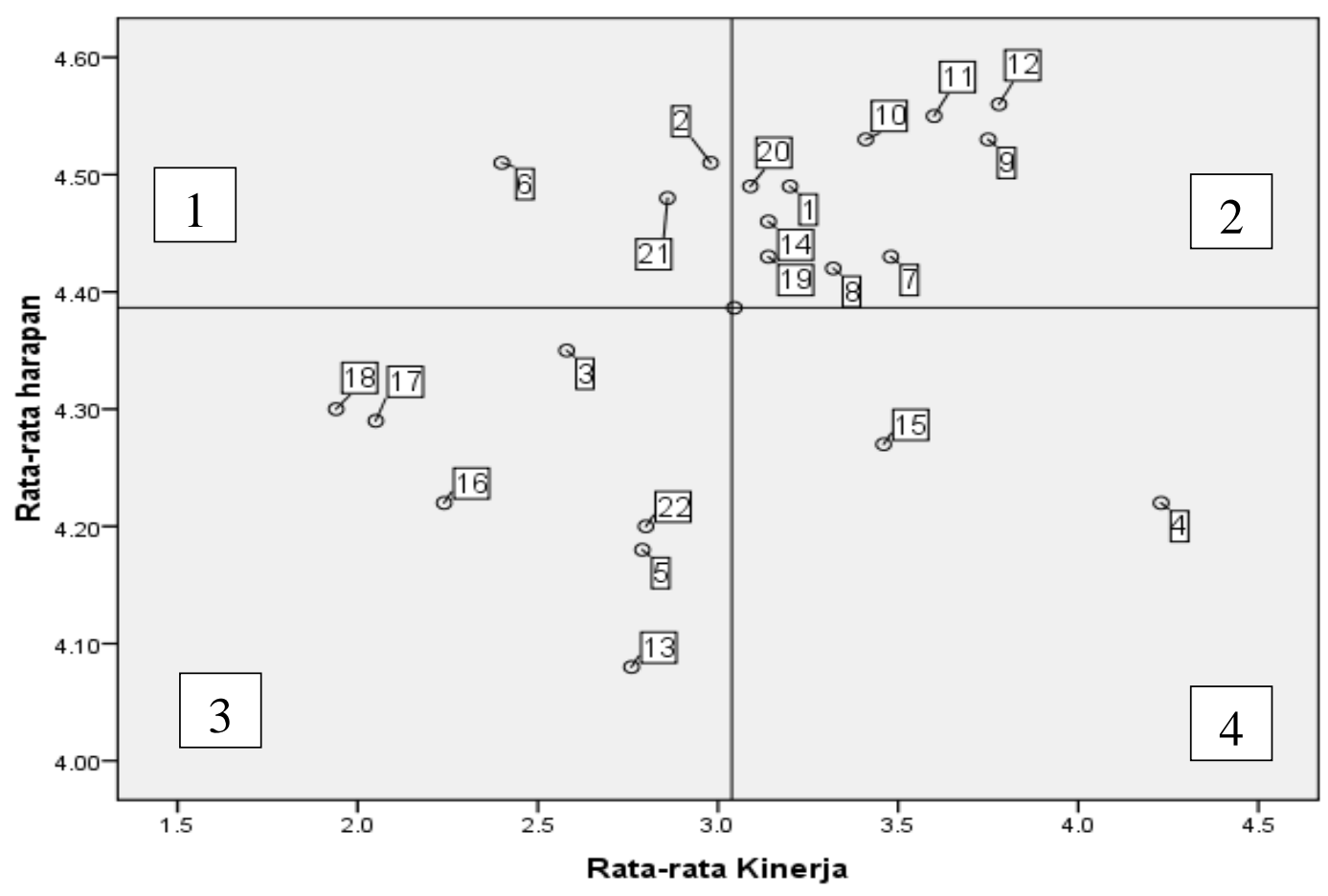

Figure 1 Cartesian Diagram of Service Quality Satisfaction 


\section{Conclusions and Recommendations}

\section{Conclusions}

The results of the research on consumer satisfaction using the Servqual method showed that the citizen was not satisfied with the performance given by Disdukcapil Bogor District. The results of CSI showed that the community was quite satisfied $(61 \%)$ but were more inclined towards dissatisfaction. This is in line with the results of the satisfaction analysis with the Servqual method, thatrevealed not all people's expectations of service have been fulfilled when viewed from the results of the gap analysis. The negative values that exist in each dimension indicate that the citizen is still dissatisfied with the performance given by the service. The results of the gap analysis also show that almost all indicators gained negative value, except for one indicator, namely the cost of service which valued 0.01, thus it is a small number and near zero. Analysis using the IPA method shows that there are three indicators in the service quality that fall into the top priority category to improve satisfaction, that is indicator 2 (ease of handling requirements), 6 (speed of service process), and 21 (facilities and physical condition of office buildings).

\section{Reccomendations}

The recommendation for Disdukcapil is to implement e-government to develop their systems to improve their efficiency, also to improve the existing facilities. Suggestions for further research are to examine satisfaction from other factors such as ease, time, etc. The selection of locationhad to be adjusted with the real situation that is hapening, it is important tounderstand the rough situationof the location of the research target first before executing the research. Open answer question isalso needed to gain more understanding about what the citizens think about improvement of services.

\section{References}

Akinloye Akinboade, O., Chanceline Kinfack, E., \& Putuma Mokwena, M. (2012). An analysis of citizen satisfaction with public service delivery in the Sedibeng district municipality of South Africa. International Journal of Social Economics, 39(3), 182-199.

Amran, T. G., \& Ekadeputra, P. (1985). Metode Kano Dan Root Cause Analysis. Jurnal Teknik Industri,ISSN:1411-, 160-172.

Anderson, E. W., \& Fornell, C. (2000). Foundations of the American customer satisfaction index. Total quality management, 11(7), 869-882.

APJII. 2017. Penetrasi \& Perilaku Pengguna Internet Indonesia 2017. Asosiasi Penyelenggara Jasa Internet Indonesia. 1-39.

[BAPPENAS]. (2010). Laporan Manajemen Pengaduan Masyarakat dalam Pelayanan Publik 2010.

[BPS] Badan Pusat Statistik. (2017). Statistical yearbook of Indonesia 2017. Badan Pusat Statistik. Retrieved 23 March, 2018 from https://www.bps.go.id/publication/2017/07/26/b598fa587f5112432533a656/statist ik-indonesia-2017.html 
Charaf, K., \& Rahmouni, A. F. A. (2014). Using importance performance analysis. Accounting and Management Information Systems, 13(4), 665.

Chen, Y.C. (2018). Applying importance-performance analysis to assess student employability in Taiwan. Journal of Applied Research in Higher Education, 10(1), 76-86.

Haq, S., Suharsono, A., \& Suji. (2014). Kualitas Pelayanan Pubik Dalam Pembuatan eKTP Pada Kecamatan Suboh Kabupaten Situbondo. Artikel Ilmiah Hasil Penelitian Mahasiswa 2014, (1), 1-8.

Hirmukhe, J. (2012). Measuring internal customers' perception on service quality using SERVQUAL in administrative services. International journal of scientific and research publications, 2(3), 1-6.

Husna, S., \& Syukri, A. (2014). Penerapan Customer Satisfaction Index ( CSI ) Dan Analisis Gap Pada Kualitas Pelayanan Trans Jogja. Jurnal Ilmiah Teknik Industri, 13(2), 103-111. Retrieved from journals.ums.ac.id/index.php/jiti/article/view/618.

Indonesia, APJII. (2017). Infografis Penetrasi dan Perilaku Pengguna Internet Indonesia. ID : APJII

Indonesia, PR. 2013. Undang-Undang Republik Indonesia Nomor 24 Tahun 2013 tentang Administrasi Kependudukan. Jakarta (ID) : Sekretariat Negara.

Negara, P. M. N. P. A., \& Nomor, R. B. (16). tahun 2014 tentang pedoman survei kepuasan masyarakatterhadap penyelenggaraan pelayanan publik. Jakarta: Kemenpan.

Parasuraman, A., Zeithaml, V. A., \& Berry, L. L. (1985). Model Service Its Quality and Implications for Future. Research Paper, 49(4), 41-50. https://doi.org/10.1016/S0148-2963(99)00084-3

Riyadi, S., Hermawan, A., \& Sumarwan, U. (2015). Kepuasan Masyarakat Terhadap Kualitas Pelayanan Kantor Pertanahan Kabupaten Indramayu. Jurnal Ilmu Keluarga \& Konsumen, 8(1), 49-58.

Tjiptono, F \& Chandra, G. (2016). Service, Quality dan Satisfaction. (4 ed.). ID: Andi Publisher.

Sumarwan, U. (2015). Perilaku konsumen. Bogor (ID): Penerbit Ghalia Indonesia.

Wallin Andreassen, T. (1995). (Dis) satisfaction with public services: the case of public transportation. Journal of Services Marketing, 9(5), 30-41.

Windyani, A. R., Hubeis, A. V. S., \& Fahmi, I. (2014). Analisis Kepuasan Masyarakat terhadap Pembuatan Akta Kelahiran di Depok, Jawa Barat. Jurnal Aplikasi Manajemen, 12(1), 32-40. 